\title{
RACIAL VIOLENCE IN WILLIAM FAULKNER'S DRY SEPTEMBER AND HARPER LEE'S TO KILL A MOCKINGBIRD
}

\author{
Iulia Andreea Milică \\ Alexandru Ioan Cuza University of Iasi, Romania
}

\begin{abstract}
With its history of slavery and racial conflict, war and defeat, segregation and lynching, the South is defined by violence and aggression on a personal and community level. This experience defined Southern identity and shaped its literature to mirror the sense of frustration, guilt and shame bursting from the heart of seemingly peaceful, ordered and decent communities. Though some authors tend to see violence as a necessary transgression that will, eventually, through painful sacrifice, lay the foundation of a renewed world, others regard it as a trap or a vicious circle which does not allow the South to grow out of the illusion of a glorious past and accept present changes. William Faulkner' short story Dry September and Harper Lee's novel To Kill a Mockingbird deal with an alleged accusation of rape, the victim being a white woman, and the culprit, a black man. Focusing more on the white community's attitude and telling the story from limited perspectives, the two texts investigate less the black man's tragedy, dwelling more on the white people's reaction and the manner in which white Southern identity and white supremacy are constructed on a foundation of violence and intolerance.
\end{abstract}

Keywords: Southern identity, racism, racial violence, lynching, white supremacy.

Lynching is considered, by many critics, sociologists and anthropologists, one of the most painful realities in the American past, testifying of the dividing race lines that have defined, in a very violent way, the relationships among the races that were meant to share the same land and claim authority over the new world:

The scale of lynching and the severity of the scars it has left on American society have caused both blacks and whites to struggle to explain this grisly manifestation of humankind's capacity for hate and violence. Indeed, so pronounced was the penchant for lynching in the United States that early observers considered it a measure of American distinctiveness. To explain the 
prevalence of mob violence was to explain much about American attitudes about social order, justice, and race. (Brundage 2)

However, if, generally speaking, relationships among different races in America are too complicated to be viewed solely in the light of a handful of manifestations, we may still assert that lynching, as a particular reflection of race hatred, is mostly considered defining for the coexistence between whites and blacks in the American South. Though violent manifestations of many sorts have scarred the Southern past, lynching, as a particular case, is mostly characteristic of the period after the Reconstruction, revealing the painful adjustment of the two races to a life of equal rights.

Lynching as such was not a post-Reconstruction invention, it had existed since the foundation of the American colonies, but it referred, then, to many other forms of punishment, such as beating, whipping, tar-and-feathering, and, only occasionally killing, and was directed less against the black slaves and more against whites who disobeyed different rules of the community (Markovitz xxiii). What we nowadays refer to as lynching mob, namely, "a crowd of people that kills someone by hanging them, without a legal trial," (LDCE) was not typically directed towards the black slaves who were forced to endure other forms of punishment. Most of the times, the slaveowner was in charge of choosing the punishment for his own slave, the community rarely interfering with affairs on the plantation, which was, more or less, a closed system. Mob violence against the black people in the form of what is now known as lynching started to be put into wider practice after the emancipation of the slaves, when the white people attempted to find new forms of controlling the masses of people who wanted more rights and aspired to equality to the white population. The number of lynchings, as mob violence against the black, grew after the Reconstruction, and coincided with the adoption of the "Jim Crow" laws, which legalized the segregation between the whites and the blacks. Lynching, therefore, became a rather widely-employed form of control of the black population by intimidating and constantly threatening them, and, in this way, promoting the idea of white power and superiority. According to Jonathan Markovitz,

Lynching was always intended as a metaphor for, or a way to understand, race relations. While there were many different types of lynchings, lynch mobs typically worked to ensure that black audiences were aware of the strength of white supremacy and the costs of violating the boundaries of the racial order; at the same time, they wanted to reinforce images of white men as chivalrous protectors of white women. (xvi)

In other words, lynching is nowadays regarded less as a form of maintaining order and law in the community, though this was mainly what the participants in 
the mob claimed, and more as a means of keeping the black population in terror and submission by proclaiming white superiority and control. Though some of the mob violence was directed against white people or other races as well, the difference between the African-Americans lynched and other Americans undergoing the same treatment is staggering. According to James H. Madison, "from 1880 to 1930 , angry mobs lynched 4, 697 Americans. Of these victims 3,344 were African Americans. Race was a central factor in this tragedy, as in many of America's tragedies." (13)

Since the South was more closely affected by racial problems than the rest of the Union, due to its past of slavery, it is widely considered that lynching was a Southern problem, though there were such actions recorded in other parts of the country, targeting Native Americans, Mexicans or Asians. Jonathan Markovitz, for instance, in analyzing the figures related to lynchings given by different authors, appreciated that lynchings became a Southern problem especially in the twentieth century when, from the number of lynchings in the United States, 95 percent occurred in the South, and the victims were primarily African American. (xxiv) The reasons why such violent actions occurred mainly in the South are very complex and many have tried to understand the mechanisms that led to these gruesome events.

Though it is quite difficult to pinpoint an exact motivation for such a penchant for cruelty in the South, there are some common elements on which critics and historians agree. The Southerners, with their individualism, lack of confidence in the institutions to enforce order, an exacerbated sense of selfworth and pride, were more eager to enforce justice (or, at least, their own vision of justice) on their own rather than rely on official mechanism of lawenforcement. W. Fitzhugh Brundage, for instance, refers to the Southern code of honor, which, though loosely defined, provided Southerners with a justification for their actions, whereas in the North, people relied more on institutions to protect their own interests:

Commentators considered it that the South, with its looser reliance on official forces to control the people and with its more enhanced sense of individualism and personal pride, was more ready to take justice in its own hands regarding any type of matter. In the north, for instance, due to the more rapid urbanization and economic development, people relied more on official authorities to protect property and thus the force of the masses was more under control. Popular justice, they boasted, reflected the vigor of both democratic and communal values in the South; lynchers defended, rather than endangered, civilization by protecting it against the threat of slave revolts and abolitionist sedition. (Brundage 2)

Thus, lynching was seen as a method through which the whites defended civilization, honor and order against the danger posed by the "uncivilized" black. However, the underlying truth of such beliefs was the fact that the whites felt 
that their position of superiority and power, especially after the emancipation of the slaves, was threatened, and the lynchings, with all their ritualized actions and the publicity surrounding them, were meant to strengthen the superior position of the whites: "A lynching was a performance that sent a message of white supremacy, warning all blacks to stay in their place. It was a weapon of terror that could strike anywhere, anytime, against any African American." (Madison 15) The same opinion is shared by Trudier Harris who comments that: "Ultimately, lynching and burning rituals functioned to sustain a belief in racial, economic, psychological, and moral superiority in whites and to reinforce a clearly designed concept of place for Blacks. Deviation meant death. Ritual served a need for whites." (18-9)

Though the desire to keep the black population under control by means of terror is widely recognized as the main factor that led to violent actions of the white against African Americans, historians have tried to underline other possible factors for lynchings. For instance, poverty and lack of education, which were more visible in the Southern states, are, sometimes, considered a trigger for mob creation and violence: "The statistics and evidence gathered by sociologists demonstrated that lynching went hand in hand with a rural culture corrupted by drunkenness, irreligion, illiteracy, poverty, and excessive license." (Brundage 7) Consequently, there was the assumption that education and the development of economy in the South would lead to a decrease and ultimately to the eradication of such violent practices. This claim is also supported by historians who demonstrated that poverty and economic depression led to competition between the white and the black workers, and consequently, the rates of lynching increased during periods of economic stagnation. (Markovitz xxv) In such a case, the resentment of the population is directed towards the defenseless and weaker group that is expected to pay for all the evils of the society in a sort of scapegoating mechanism of release of social frustrations.

Most justifications for acts of cruelty against the African American are based on the racial lines dividing the population of the South, suggesting that race difference alone may justify outbursts of violence. However, commentators have tried to go deeply into the core of the matter, investigating other factors such as the gender of the victims, as well as the crimes for which they were killed. According to statistics,

Between 1882 and 1927, an estimated 4,951 persons were lynched in the United States. Of that number, 3513 were black and 76 of those were black women. Murder, rape, and "minor offenses" were the major causes of lynchings and burnings [.... of the 2060 Blacks lynched for "various causes" between 1882 and 1903, 783 were lynched for murder, 707 for rape ("... either attempted, alleged, or actually committed") and 208 for "minor offenses"; many were also burned or "roasted alive." [...]This percentage is significant because the primary motivation for the ritualistic lynchings depicted by black writers centers upon crimes 
allegedly committed by black men against the persons of white women. Protecting white womanhood became the emotional stimulus to a mob. (Harris 7)

Therefore, it is quite interesting that among the primary accusations resulting in the formation of a lynch mob is the alleged offence of a black man against a white woman. In the Southern imagination, the white lady represented a symbol of honor and purity. The only purpose of a "Southern belle," when she was young, was to marry and then become an honorable matron, testifying of the family's pride and high status. This stereotypical image of the Southern lady was perpetuated both in literature and in non-literary texts. Thomas Nelson Page, for instance, in his essay Social Life in Old Virginia gives an idealized presentation of the Southern lady which, though not in keeping with reality, was widely accepted by people at the time: "What she really was, was known only to God. Her life was one long act of devotion, - devotion to God, devotion to her husband, devotion to her children, devotion to her servants, to her friends, to the poor, to humanity. Nothing happened within the range of her knowledge that her sympathy did not reach and her charity and wisdom did not ameliorate." (35) The image of outer fragility and inner strength, of devotion to God and to family, of self-sacrifice for the sake of the others, of shyness and purity became the trophee for which the white man was expected to go to battle. She is more than a woman, the Southern lady becomes a symbol of the South itself, (Seidel xiv) she is "not a human being," but "a marble statue, beautiful and silent, eternally inspiring and eternally still. ... the Southern lady is at the core of the region's self-definition; the identity of the South is contingent in part upon the persistence of its tradition of the lady." (Jones 4) Because of this representation of the white woman, the white man becomes a "cavalier" prompted by her delicacy and weakness to take action against any enemy. And the enemy is, quite often, the "uncivilized," "rough" and "savage" black man. Any connection between the black man and the white woman is inconceivable and therefore can only be the result of rape. It is, then, the duty of the white man to protect his honor by protecting that of the white woman and immolating the black offender.

White myths of black male sexuality created images of a savage beast consumed by lust for white women. In this fantasy whites were civilized, blacks were uncivilized. White women were the "purest" form of civilization, black men the most savage and "unclean." Sex between a black man and a white woman was a defilement of the ultimate sort. Sexual attraction opened up the possibility of a genuine human relationship, with the potential even of equality between a black man and a white woman expressed in sex and even love. Part of this story included the fear of some white men that white women were sexually attracted to black men. Moreover, such a relationship was liable to produce "mixed" and therefore "unclean" offspring. White women, so white men wanted to believe, would never willingly engage in sexual relations with a black man. Only rape 
provided lustful black men with sexual access to white women. In such tangled webs of race and gender, white men were obliged to protect white women. Men who protected white female purity were also protectors of community values and of civilization itself. (Madison 14)

Thus, according to James H. Madison, there are various reasons that led to the creation of this negative image of the black man in the white Southern imagination and hence the need to punish any form of transgression of gender and racial borders. It is the fear of sexual competition, of miscegenation and ultimately, of the destruction of a myth that formed, for a long time, the basis of white identity, namely the superiority of the white race that justified the power and control of the white over the black.

The two texts under discussion, the short story Dry September by William Faulkner and the novel To Kill a Mockingbird by Harper Lee are both structured around a lynching episode caused by the accusation that a black man raped a white woman. The presentation of how the white community reacts to such accusations becomes a justification for deeper introspections into the Southern culture and mentality, into its prejudices and traditions. Dry September was published in Scribner's Magazine in 1931 and, though To Kill a Mockingbird was only published in 1960, it refers to events occurring in the 1930s, creating, thus, a common temporal background, coinciding with the peak of lynchings in the South and also with the period of economic Depression. It is the focus of the two texts that actually separates them. Published during the period of segregation and racial hatred, and in accordance with the prevalent opinion of that time, Faulkner's text emphasizes the influence of the mob that erases any individual atempt to oppose it. Harper Lee, on the other hand, treats the topic differently, as the time of the publication of the novel coincides with the Civil Rights movement marking a change in the attitudes concerning racial divisions and violence. Consequently, she is allowed a certain detachment from the actions of the 1930s, focusing on characters who promote tolerance and reconciliation, and who give up mob violence in favor of institutionalized forms of justice.

The two stories are set in regions where segregation, poverty and prejudice were hard to uproot. Both Mississippi (Faulkner's region) and Alabama (the state where Lee's Maycomb is located) were Southern states still indebted to pre-Civil War distinctions of class, gender and race, and where poverty and economic depression took their toll on the population. In a survey covering the lynchings in the Unites States between 1882 and 1962, Mississippi is on the first place with a total of 538 African American killed, and Alabama is on the fifth place with 299 victims (Lynching by State and Race).

Another similarity between the two texts is the motivation for the mob formation which is an accusation of rape, linking, thus, the racial conflicts 
inherent in the Southern regions to gender conflicts. Moreover, in both cases, the alleged rape is only a pretext for the white men to reassert their power. Their true intentions are hidden under a fake pretence of honor. It is clear for the readers from the very beginning that the women who were supposedly raped were far from being symbols of purity and honor, that they were never actually raped and so, the gratuity of the lynching act is highlighted.

In the case of Faulkner's short story, there is no clear indication of any particular event that might have influenced the writer in writing this particular text, nor is there any clear indication of the time of the story. The fact that one of the characters, McLendon, who becomes the leader of the mob party "commanded troops at the front in France" and "had been decorated for valor" may place the action anywhere in the 1920s and the beginning of the 1930s. However, Faulkner could have had a rich source of inspiration in the events occurring in Mississippi and also in other states at that time, some of them highly publicized. The Mississippi Delta was called by James Cobb "the most Southern place on earth" being overwhelmingly rural and poor, dominated by "the economics and politics of cotton" and by dreams of "white supremacy and a history of lethal mob violence against African Americans." (Griffin, Clark and Sandberg 35). It was, therefore, a place where even a minor or alleged offence of a black against a white would not go unpunished.

As far as Harper Lee's novel in concerned, critics agree that there is a clearer source of influence: the famous Scottsboro Trials in Alabama in the 1930s. Nine black men were accused, trialed and convicted for having raped two white women. The accused were judged and sentenced in a rush, three-day trial. As a result, the Scottsboro boys went through several appeals and new trials that enflamed the spirits both in the North and in the South: all these events drew attention on prejudiced, all-white juries that tended to protect the white instead of upholding justice.

Both texts rely heavily on white identity and white supremacy, on how they are created, what unites the different members of a race in violence against the other race, why they resort to mob violence and distrust institutional action, on why the mob members feel the need to protect an otherwise shallow dream. On the other hand, the stories differ in the way in which the mob carries out its decision to punish the culprit. If in Faulkner's story the black man is unjustly murdered by a small group of white men, in Lee's story the mob's intention is averted. In spite of that difference, both stories are indicative of Southern mentality and of the way in which white identity is shaped, through imposition of violence as well as through appeal to tolerance and reason, suggesting how complicated or misleading it would be to apply simplistic and unilateral value judgments when analyzing regional mentalities.

In their study on lynching, Larry J. Griffin, Paula Clark, and Joanne C. Sandberg argue that there is a situation that is not properly discussed or taken 
into consideration, namely that of averted lynching. Though statistics about the number of lynchings are very important, the researchers argue, it is also crucial to see what happens during the lynching, how it started, when and how it could be stopped. Generalizations are helpful, but it was demonstrated that in very similar situations, actions could take a different turn due to apparently meaningless causes. This does not mean that the lynchings were random happenings, but, the researchers comment, the analysis of the unsuccessful lynchings may also reveal important insights into understanding the mechanisms of white supremacy. (28) An averted lynching could tell as much about the Southern world as a completed one, since it is as interesting to notice who or what stopped the violence, who and what has the power to control the masses, or how the mentality of the white southerner may (even slowly) change towards a more tolerant outlook.

Structured in five parts, Faulkner's short story does not involve the participation of the black community, the voice of the black being silenced, as it has long been in the South, except for a brief presence of the lynched victim before death. The text, thus focuses solely on the identity of the white, both private and public, shaped by social and cultural pressures, on the one hand, and individual frustrations and resentment, on the other. The characters try to define themselves according to long-established codes and expectations, but their individual features and their private desires and longings make it hard for them to fit their ideals with their realities. The frustrations connected to their present unsatisfying conditions lead to vengeance against the marginal, the black man. This interest in the white man's reactions is visible also in the fact that, though the formation of the lynching mob, with all the opinions for and against taking action, as well as the capture and beating of the accused are presented in detail, the moment of the lynching itself with the image of the dead body is not depicted at all, in spite of the fact that, at the time when the story was published, American newspapers were eager to present all the gruesome details of lynchings with revealing photos. Instead, the story almost unexpectedly ends with the image of the leading participant in the lynching in his own home, and reveals the fact that Faulkner consciously deprives the eager reader of sensational details, in favor of a deeper insight into the psychology of the mob.

The story, set against the background of a dry September day, a "durn weather ... enough to make a man do anything," (Faulkner 170) is centered around three main white figures: the leader of the lynching mob, McLendon, presented as the prototype of the white Southerner, former war hero, a man accustomed to violence and ready to use it to defend the defenseless: the white women and children (as he states); the alleged raped lady, Minnie Cooper, the one who causes all this turmoil and whose honor needs to be protected, and, finally, the barber, Hawkshaw, the one who dares, at least for a while, to be different and speak the voice of reason in a context dominated by emotion. 
Marjorie Pryse sees the characters in Dry September as marked and unmarked, as far as their identity and social integration is concerned, the insistence being on "invisibility" rather than visibility or "being marked:" "By making manifest ambiguities within a white society (the blackness within white) and casting them out by "out-caste-ing" the racial deviant (marked by skin color), the members of the society protect their homogeneity, their aggregate invisibility." (95) In general, violence is directed against the marked individual, the one who deviates from the norm and becomes different. In this case, the difference comes from racial identity and the violence of the white community is directed towards the racially marked while all the other members of the white community try to appear as "unmarked" and indistinguishable in the crowd.

The first part presents the creation of the mob out of apparently ordinary people who were not all willing, at the beginning, at least, to become violent, but were only gossiping the latest news. On the dusty, hot September day, they all appear uniform, homogenous, "unmarked", referred to as "the client" or "another" up to the point where it is difficult to say exactly how many people participate in the scene. Only few are slightly individualized and their role in the action is a little more defined. The first one is the barber named Hawkshaw "he was a man of middle age; a thin, sand-colored man with a mild voice." (Faulkner 169) In fact, Hawkshaw, the barber, McLendon, the leader, and the black victim, Will Mayes, are the only ones clearly identified by name in this scene. The other two characters who become a little more visible in the group are a young man who appears to be named Butch (though, another client keeps calling him Jack) and a drummer. These last two are united in their willingness, from the very beginning, to adhere to a code of behavior typical for the ideal of white Southern supremacy: asserting their masculinity in the protection of the white women from any type of injury, defending their belonging to a white group superior to the black, proud of their inclusion in the white Southern caste, ready to accuse others of being "nigger lovers" and eager to use violence to administer justice without appealing to legal procedures. For them, those guilty for all the wrongs in the South, in their opinion, are the "Northern" and the black. They are the first ones who start calling anyone who tries to appeal to reason a "nigger lover" which is a form of marking of that person by including him in the group of those marginalized and in danger of suffering the same outbursts of violence reserved for "the marked." But though Butch and the drummer are verbally violent, they are still not ready to resort to action.

The other clients and barbers in the shop remain largely undistinguishable, siding neither with the violent white, nor with the black man. Their suspicion that everything is a rumor comes from their knowledge of the behavior of the alleged victim, Minnie Cooper, and they mostly plead for time to discover the facts. However, they do not do much to stop the murder. Thus, they still identify themselves as belonging to the group of the white, unwilling to give 
up their "invisibility", unlike Hawkshaw who endangers his position by being the only one who openly defends the black man. In other words, this scene reveals the fact that, even if not all the Southerners were ready to murder a black man or woman and that not all crowds turned into lynching mobs, it is obvious that the dividing color lines were still a painful reality in the South of the late 20s. Except for the barber, none is willing to side with the black man and see him as an individual, though most of them appear to know him. They never speak of him, never pronounce his name, but would be willing to wait and see how the official investigation goes, rather than go and kill him themselves.

The arrival of McLendon in the barbershop is the decisive moment when the group talking, even though heatedly, over the topic, turns into a lynching mob. He is the one who demonstrates to them that it does not really matter if Mayes did it: "Happen? What the hell difference does it make? Are you going to let the black sons get away with it until one really does it?" (Faulkner 172) It is clear, therefore, that this particular occasion is far from being an episode of bringing to justice an offender and, just like the others, McLendon does not believe that the black man, by the name of Will Mayes, did it, or that the woman, Minnie Cooper, was actually raped. It is, for them, a ritualistic means of freeing their own frustrations and anger in asserting their superiority and importance when all the evidence suggests that they lead empty lives. McLendon, the former war hero, sees an opportunity that would bring him again, from a shadowy corner, into the spotlight, as a leader of men. His tone and attitude are commanding, even threatening, clearly defining the position that they are expected to adopt: "All that're with me get up from there. The ones that aint..." He roved his gaze, dragging his sleeve across his face." (Faulkner 172) The status of belonging to a group, being integrated in that group, irrespective of sharing the same opinions or not, is much more important than becoming the marginal, the one under constant threat and danger, and McLendon is certain to be threatening. Belonging to a group also leads to shared feelings which prevent guilt or fear of being accused:

Acts of ritualized violence require group participation in order that the individuals involved may avoid feelings of guilt. The procedure can be compared to that used in firing squads where all squadsmen must fire at the victim and thereby be blamed and blameless, guilty and guiltless. The concept of law and order destroyed the offender, not the men pulling the triggers. In like manner, various concepts, not individuals, destroy black victims. (Harris 12)

In the end, all of them, one by one, willing or unwilling, join the group set to kill the black man: "Another rose and moved toward him. The remainder sat uncomfortable, not looking at one another, then one by one they rose and joined him." (Faulkner 172) Even Hawkshaw, the most reluctant of them, leaves the 
shop with the thought of stopping them. Unfortunately, by the time the barber reaches them, even the more reasonable ones have fully joined into the beliefs of the mob and when they catch Will Mayes, they all become an undistinguishable group of murderers: "Kill him. Kill the son" a voice whispered." (Faulkner 177) - an unidentified voice in a group in which individual differences are erased.

Hawkshaw does not manage to prevent the murder because he does not go all the way with his attempt to change the course of actions. His visibility, by siding with the black man, already became too obvious and, though he chooses to jump from the car and not participate in the killing, he feels the pressure of his action and fears the consequence. His break from the group exposes him, and when the cars returns, after the killing of the black man, he hides into the ditch until they pass. According to Marjorie Pryse, Hawshaw refuses to share the black man's visibility and expose himself for crucifixion, and, by jumping out of the car, he tries "to retain his invisibility of whiteness in a white and black world" (98) suggesting that the pressure of class and race identification is much more powerful than humanity, or pity, or justice. Hidden in the dark ditch, he becomes "invisible" again, and safe, but at what cost?

Minnie Cooper, the accused lady in whose name a murder is committed, is also clearly distinguishable from the group of white women. From the very beginning, half-uttered truths and ambiguous statements suggest that the participants in the discussion do not really believe that the rumor about Minnie's rape could be true: "She's about forty, I reckon. She aint married. That's why I dont believe -", (Faulkner 169) says the barber. Another client tries a joke: "It's enough to make a man do anything. Even to her." (170) But nobody laughs. There are also antecedents about Minnie: "This aint the first man scare she ever had, like Hawkshaw says. Wasn't there something about a man on the kitchen roof, watching her undress, about a year ago?" (171) In this way, a clear-cut distinction is created between Minnie Cooper as a particular woman, and the general idea of "Southern lady" that they are supposed to defend suggesting the fact that realities do not rise up to the ideal identity that these people want to create for themselves. Even in her youth, Minnie appeared to be "a little brighter and louder flame" (174) for which the other women in town envied her. Growing into her forties and unmarried, she had an improper relationship with a bank cashier and now, the rumor goes, there is a scent of whiskey in her breath, again inappropriate for a Southern lady. The two sections of the short story dedicated to the portrayal of Minnie Cooper enhance the fact that the ideal for which these men kill an innocent is not supported by reality and point out the meaninglessness of the lynching. The much-appraised ideal of Southern lady is as shallow as that of white supremacy.

In fact, what Minnie tried to do with her accusation is return to a form of "invisibility" that means acceptance in the group of peers. She can do this only if all the others unite around her for a common cause, which they actually do. 
When she becomes the center of their interest, Minnie is no longer the brighter flame envied by all the other women, but a "fragile" lady: "They entered the square, she in the center of the group, fragile in her fresh dress." (Faulkner 180) Just as in the case of Hawkshaw, Minnie achieved, in the end, a sort of "invisibility" equal to a form of acceptance in a group, and again, at what cost?

The last part of the story is dedicated to the leader of the lynching mob, John McLendon who, up to that moment, was the only character in the story who seemed to live up to the ideal that he imposed to himself and to the others. Former war hero, decorated for courage, standing up for the women in town, clearly respected and even feared, according to the way in which he is obeyed, McLendon appears as the typical white middle-class Southerner who adheres to the myth of white supremacy, upholds the idea of "Southern pride" and lives his life according to a well-established and highly-honored code of behavior. Thus, his public image appears as the only one in which there is a coherence between reality and ideal. His private life, however, disagrees with his public attitude. Back at home, in his small white house, he finds a terrified wife who fears his gestures out of the experience of a long life of abuse. The man who posed as a defender of women is, in his own family, an abuser.

Faulkner's short story, therefore, deconstructs the stereotypical images that are used in the creation of Southern identity suggesting that violence and intimidation are not only meant to keep the black people under control, but also to force white people intro already established patterns of behavior and make them ignore the changes brought about in the modern world or desert the common cause, however unfair it might be. Thus, even if Hawkshaw tries to transgress the color lines and appeal to reason, he withdraws quickly into white invisibility not to expose himself too much and risk endangering his position and even his life. Minnie Cooper, after having transgressed the boundaries of her position by being a "brighter" flame than the rules of society allowed for women, is forced back into a group of pitying women, into a position of inferiority. McLendon, the hero, proves, in the end, to be only a frustrated man who typically uses violence against the weaker, women or men, intimidation and terror being the only ways he knows to assert his masculinity and to feel important, no matter whom he harms in the way. The question is, again, at what cost? The life of Will Mayes is wasted, he is killed not for a crime, not even for an ideal, and the stifling atmosphere of that dry September day, Hawkshaw's shameful hiding, Minnie's collapse or McLendon's frustration leave the story without a closure, giving the impression that the world is caught in a vicious circle of violence, frustration and shame out of which there is no visible escape.

In Harper Lee's novel, the characters are more clearly defined and placed in more various categories than in Faulkner's short story, but, ultimately, the basic truth remains the same: people, no matter how different they may be, socially or economically, see themselves within color lines and those belonging 
to the privileged race tend to cross all social differences to preserve their superior racial position, even at the cost of the murder of an innocent victim. Just like in Faulkner's short story, the spirits are heated by an accusation of rape: the offender being a black man, Tom Robinson, known as a hard-working, serious family man and the victim, Mayella Ewell, a white-trash girl who, in normal circumstances, would be placed in the lowest position of social importance, but who, on this particular occasion, becomes the center of the community's antagonisms.

If, in Faulkner's text, the black victim remains silent, in Lee's novel there is a trial with extensive depositions which complicate the matter of racial division. The transgression of the black man is not so much for having allegedly raped a woman, as for testifying that she tried to abuse him. Tom Robinson's deposition reveals the fact that Mayella Ewell tempted him and, then, rejected by him and on the verge of being caught by her father, she threw in the accusation of rape. Moreover, Tom Robinson, the black man, had the audacity to say: "I felt right sorry for her, she seemed to try more'n the rest of'em -" (Lee 197) referring to the fact that she was the only one in the family who worked and tried hard to take care of all the children - that is, to conform to social requirements and try to live a different life than her "trashy" family. A white woman having a preference for a black man was unheard of in the segregated South, a black man feeling pity for a white person was downright unacceptable. Normal relationships among people are considered abnormal if they cross the color lines. Moreover, such a behavior of a white woman, even belonging to the lowest class is equally unacceptable, and, it is preferable to find another scapegoat for her transgression rather than publicize such a shameful reality within the white community. It is, on the part of Mayella Ewell, evident fear of immediate punishment from her father. But it is also the fear of the white society in general. White people in the South fear that, if such behaviors are accepted and justice is served properly, more dark truths about white identity and supremacy or white and black relationships could be revealed.

Both texts display a clear separation of people along color lines, especially when the white, no matter how different they may seem from each other, become united in racially marked groups trying to defend "a rigid and time-honored code of our society, a code so severe that whoever breaks it is hounded from our midst as unfit to live with." (Lee 203) The world of Maycomb, Alabama, as it is seen through the eyes of the observers, the young girl Scout and of her brother Jem, is divided into several categories: the family and close neighbors forming the respectable people in town, who lead their lives according to long-established codes of behavior and who can testify of their importance by being able to count several generations in this town. The second group is that of the simple but hard-working people, most of them affected by the Depression. The Cunninghams from Old Sarum become individualized and 
representative for the group, playing an important part in the story and pointing out the difficulty of seeing people as strictly good and evil. Though poor and struggling hard, they are proud people who "never took anything they can't pay back - no church baskets and no strip stamps. They never took anything off of anybody, they get along on what they have. They don't have much but they get along on it." (Lee 20) The Cunninghams and the others like them are the best candidates to form a lynching mob: they are not "aristocratic" enough to have codes of mannered behavior, and they are poor and frustrated enough to need outlets for their tension. At the opposing side there is another category epitomized by the Ewells, typically belonging to what the Southerners call "white trash:" "Atticus said the Ewells had been the disgrace of Maycomb for three generations. None of them had done an honest day's work in his recollections. ... They were people but they lived like animals." (Lee 30) They are poor, lazy, dirty, the father is always drunk and the children never finish school. Though despised by the Cunninghams and the rest, they are united with them by displaying the same bigotry and race pride without nuances and distinctions. Finally, there is the group of the black people, presented in the novel in a positive light especially due to the children-observers' attachment to their nanny Calpurnia. These are the categories that will participate in the trial of Tom Robinson revealing the prejudice and the hidden appetite for violence residing in an apparently quiet Southern town.

The tension that culminates with the attempted lynching of Tom Robinson is built up gradually. It starts with accusations directed especially at Atticus the moment he accepts to defend the black man. From the attitude of the people, it is clear that education and wealth are not compulsory factors in a more correct understanding of race relationships. Thus, Scout finds out in school that her father is a "nigger lover" and though she does not exactly understand what that means, she realizes that it is not an appreciative comment. This attitude will recur, coming from cousin Francis, Mrs. Dubose, one of their upper-class neighbors, and from some country folk the children encounter in the street, suggesting the fact there is a willingness to label and categorize people and an appetite for violence, in words and gestures. The segregated South, therefore, is only apparently a world of manners and civilization, and it rather rests on prejudice and intolerance

However, an important distinction is created among the social classes in Maycomb, regarding not necessarily their attitudes towards the events, but mostly their willingness to act, rather than talk. Though members of the upper layers of the society of Maycomb may disagree with Atticus' decision and verbally express their disagreement, there is still a rational attitude that makes them wait for the trial. Moreover, some of the people have the sensibility to ponder over the case by looking at the evidence, namely not the fact that a black man raped a white girl, but the fact that Tom Robinson is a respectable man 
while the Ewells are not trustworthy, removing the racial "marks" and drawing the particular individuals from invisibility. The poorer people, on the other hand, are more inclined to see their world clearly divided in color lines, and though, within the white race, there is contempt for the socially lower, visible in the scornful and authoritative attitude in school of the little Chuck Little towards one of the Ewell boys, indicative of the attitude of their families, they are united in their hatred of the black and ready to take action. They are the ones who form the lynching mob and confront Atticus, the representative of justice.

In the lynching episode, in both texts, the focus is on the antithesis between reason and emotion, suggesting the fact that these violent outbursts are the result of uncontrolled emotions that could have been avoided by adopting a more rational attitude. Frustration, poverty, lack of education, or fear of being exposed are reasons for emotional bursts and violence is only superficially restrained by reason. Faulkner's Hawkshaw knows it as well as Lee's Atticus, and this is why they strive to prevent the escalation of emotion for fear it would lead to violence. Their fear is justified by a deep knowledge of the Southern typical behavior, making Hawkshaw repeatedly appeal to reason and repeat the name of the black victim in a vain attempt to make people aware of their mistake, while Atticus decides to defend the prisoner single-handedly before the trial. Therefore, even in a world of racial discrimination, there are people who attempt to appeal to reason, and risk becoming "marked," just as there are people who always prefer the safe hiding place in the shadows of racial invisibility, in spite of their innermost beliefs; they participate in a mob without assuming individual responsibility and substitute their own prejudiced beliefs to pretenses of justice and order. That is the reason why in Lee's novel, just as in Faulkner's short story, there is a lack of individualization in the description of the mob participants, highlighting their desire to be invisible, "unmarked" counterbalanced by Atticus's attempt to individualize them, "mark" them by their names:

In ones and twos, men got out of the cars. Shadows became substance as lights revealed solid shapes moving toward the jail door. Atticus remained where he was. The men hid him from view. "He in there, Mr. Finch?" a man said. "He is," we heard Atticus answer, "and he's asleep. Don't wake him up." In obedience to my father, there followed what I later realized was a sickeningly comic aspect of an unfunny situation: the men talked in near-whispers. "You know what we want," another man said. "Get aside from the door, Mr. Finch." "You can turn around and go home again, Walter," Atticus said pleasantly. "Heck Tate's around somewhere." "The hell he is," said another man. "Heck's bunch's so deep in the woods they won't get out till mornin'. (Lee 151)

Atticus's children, observing the scene from a distance do not distinguish the faces that seem to them alike in their decision to punish the alleged rapist. The 
little girl, Scout, feels the uneasiness of the moment, receptive to the charged emotional atmosphere, but without realizing the real gravity or the reason why it happened: "There was a smell of stale whiskey and pigpen about, and when I glanced around I discovered that these men were strangers. They were not the people I saw last night. Hot embarrassment shot through me: I had leaped triumphantly into a ring of people I had never seen before." (Lee 152) She realizes that she is supposed to know these people, but she is unable to recognize them. She is just as child who does not understand the importance of social identification over truth, the safety of being "unmarked" over the danger of being moral. The turning point of the episode comes the moment when one of the participants, Mr. Cunningham, is forcefully taken out of anonymity and becomes "marked". Scout sees him, reminds him that Atticus helped him and that his son goes to school with her. Exposed in such a way, unprotected by the anonymity of the mob, he dares no longer break the rules and stops the lynching. Unprotected by the invisibility of the mob, Mr. Cunningham is forced to assume an individual identity, marked by personal relationships, responsibilities and obligations. The victim is saved, the trial will decide his fate and there is, apparently, still hope for change. Mr. Cunningham is saved as well. Helped by Scout, he will not doom his soul with a gratuitous murder, like McLendon and Hawkshaw.

Nevertheless, the ending of the novel is as frustrating as that of Faulkner's story. The acts of violence continue, suggesting that one averted lynching does not completely alter the mentality of the people. Though saved by an innocent white girl from lynching, Tom Robinson dies in the segregated prison, shot by the guards while trying to run away:

"Didn't they try to stop him? Didn't they give him any warning?" Aunt Alexandra's voice shook. "Oh yes, the guards called to him to stop. They fired a few shots in the air, then to kill. They got him just as he went over the fence. They said if he'd had two good arms he'd have made it, he was moving that fast. Seventeen bullet holes in him. They didn't have to shoot him that much. Cal, I want you to come out with me and help me tell Helen." "Yes sir," she murmured, fumbling at her apron. Miss Maudie went to Calpurnia and untied it. "This is the last straw, Atticus," Aunt Alexandra said. "Depends on how you look at it," he said. "What was one Negro, more or less, among two hundred of 'em? He wasn't Tom to them, he was an escaping prisoner." Atticus leaned against the refrigerator, pushed up his glasses, and rubbed his eyes. "We had such a good chance," he said. "I told him what I thought, but I couldn't in truth say that we had more than a good chance. I guess Tom was tired of white men's chances and preferred to take his own." (Lee 235)

Ironically, the black man is killed while supposedly under the protection of justice, suggesting that mentalities cannot be easily altered. In conclusion, Lee 
tried to focus on individuals, seeing in individualization the only solution to mob murder, since people can no longer hide in their invisibility without assuming responsibility. With all the benevolence of the representatives of justice in Maycomb and the faith of Atticus in the result of an appeal, the violent death of Tom Robinson shows that beyond the borders of the little town of Maycomb, racial prejudice and hatred still rule, even in official circumstances. Tom Robinson, himself, born and raised in a segregated world, does not trust the promises of the white people or their justice, deciding to take a chance and run, provoking the guard into reacting.

Both texts seem, therefore, to foreground the importance of individualization. Throughout Lee's novel, the children try to understand their world, to operate with the distinctions and categorizations they learnt from the members of their community and social group. In the end, Scout realizes the futility of such categorizations: "Naw, Jem, I think there's just one kind of folks. Folks." The South has been seen in white and black, conflicts reduced to simple assertions and value judgments, and people placed in categories. Then, swiftly, definitions were made, without taking into account the nuances that interfere in the study of human nature. Society wants people "unmarked," compliant with the roles allotted to them and upholding the prevalent behaviors. Humanity is, however, "marked," people are different, opinions and mentalities change. Visibility and an acceptance of difference go hand in hand with assuming individual responsibility. This is exactly what these two texts want to imply. Relationships among people cannot draw on abstract principles, but on individual connections and affinities and people need to be judged according to what they are as individuals, not as representatives of a race, gender group or class. The dry, September day of violence, depicted by Faulkner, has a chance of redemption at the end of Lee's novel, with Atticus telling his little girl that people are actually nice "Most people are, Scout, when you finally see them" (Lee 281, emphasis mine), implying that, beyond invisibility, there is truth and kindness that await to be revealed.

\section{Works Cited:}

"Lynching by State and Race 1882-1962". ChickenBones: A Journal for Literary and Artistic African-American Themes, Web. February 20, 2011, http://nathanielturner.com/lynchingbystateandrace.htm.

Brundage, W. Fitzhue. "Introduction". Under Sentence of Death. Lynching in the South. Ed. W. Fitzhue Brundage. Chapel Hill and London: The University of North Carolina Press, 1997.

Faulkner, William. Dry September. Collected Stories of William Faulkner. New York: Random House, 1950. 
Griffin, Larry J., Paula Clark and Joanne C. Sandberg. "Narrative and Event. Lynching and Historical Sociology". Under Sentence of Death. Lynching in the South. Ed. W. Fitzhue Brundage. Chapel Hill and London: The University of North Carolina Press, 1997.

Harris, Trudier. Literary Lynching and Burning Rituals. Indiana University Press, 1984.

Jones, Anne Goodwyn. Tomorrow Is Another Day. The Woman Writer in the South, 1859 - 1936. Baton Rouge and London: Louisiana State University Press, 1981.

Lee, Harper. To Kill a Mockingbird. New York and Boston: Grand Central Publishing, 1982.

***Longman Dictionary of Contemporary English (LDCE), Longman, New Edition, 2003

Madison, James H.. A Lynching in the Heartland. Race and Memory in America. Palgrave Macmillan, 2001.

Markovitz, Jonathan. Legacies of Lynching. Racial Violence and Memory. Minneapolis: University of Minnesota Press, 2004.

Page, Thomas Nelson. Social Life in Old Virginia before the War. New York: Charles Scribner's Sons, 1998 electronic edition. Web. March 12, 2011, http://docsouth.unc.edu/southlit/pagesocial/page.html

Pryse, Marjorie. The Mark and the Knowledge. Social Stigma in Classic American Literature. Ohio State University Press for Miami University, 1979.

Seidel, Kathryn Lee. The Southern Belle in the American Novel. Tampa: University of Florida Press, 1985. 